\title{
EMPIRICAL ANALYSIS OF THE ENVIRONMENTAL KUZNETS CURVE FOR ATMOSPHERIC POLLUTION AND ECONOMIC GROWTH IN ALGERIA
}

\author{
MOHAMMED TOUITOU ${ }^{1}$
}

\section{Empirická analýza environmentálnej Kuznetsovej krivky znečistenia atmosféry a hospodársky rast Alžírska}

\begin{abstract}
This study aimed at examining the Environmental Kuznets curve hypothesis for Atmospheric pollution and economic growth in Algeria, in the period 1980-2017. As indicators of pollution emissions were chosen CO2 emissions per capita (PECO2), SO2 emissions per capita (PESO2), and NOx emissions per capita (PENOx). To prove these relations, we are using time series data in Vector Autoregression model supported by cointegration tests. The results indicated that the assumption of Environmental Kuznets curve was confirmed for the case of Algeria, where the mapping showed us a curve in inverse U-shape Environmental Kuznets curve characterized by a rising phase that peaked when the level GDP was highest to move to a new downward phase where environmental quality is improving over time. In terms of the direction of causality, we identified a causal relationship to Granger from GDP to the different emissions, which justifies that the implementation of a range of measures protecting the environmental quality of Algeria should be the top priority in the context of sustainable development and enhancing the long-run growth. To reduce pollution emissions, Algeria is called upon to increase significantly the use of renewable energies and the establishment of a more efficient energy policy.
\end{abstract}

Keywords: Environmental Kuznets Curve EKC, pollutant emissions, economic growth, VAR model, Algeria

JEL Classification: O44, O10, Q57, C3

\footnotetext{
${ }^{1}$ Assoc. prof. Touitou Mohammed, University of Algiers 3; Algeria, e-mail: touitou.mohammed@univ-alger3.dz
} 


\section{Introduction}

It was the 1700 s of ancient times that saw the industrial revolutions resulting in a radical transformation of the organizational system into a productive fabric based in particular on the use of energy as a motor for the completion and accomplishment of the economic activity. This is particularly a transformation by moving to a commercial and industrial company whose main objective was oriented towards economic growth and improvement of the productive system.

Currently, the awareness of protecting the quality of the environment from degradation and natural disasters, whose causes can be attributed to global warming, climate change and negative externalities; has become a primary concern of policy makers in many countries around the world.

The adoption of the Paris Agreement is a milestone in international climate politics and brings years of near deadlock negotiations to a conclusion. The Agreement creates a global process of engagement, follow-up, regular stocktake exercises, and cooperative action. The Paris Agreement aims to hold global temperatures 'well below $2^{\circ} \mathrm{C}$ above pre-industrial levels and to pursue efforts to limit the temperature increase to $1.5^{\circ} \mathrm{C}^{\prime}$ (Streck et al., 2016).

They have considered this new orientation in their policies aimed at developing and advancing the growth of their countries in the context of scarcity of wealth. These are the 1950s; during which advancement and acceleration characterized Asian and American countries; which influenced the orientations of all countries to be aware of environmental protection and the consideration of efficient use of resources, (Perroux, 1991), which was not the case for the Middle East and North Africa (MENA) region.

For a good reason, the neglect of the environmental dimension in long-term policies during these years was justified at the level of the statement of the regional environmental adviser of the Middle East and North Africa (MENA) region for the World Bank by asserting that fifteen years later, interest in the environmental issue leapt forward and the region moved from zero investment in environmental protection to investment in individual countries. Subsequently, at the beginning of 1999, a sudden and important change resulted which gave a new and decisive orientation of the Middle East and North Africa (MENA) region towards the concern of environmental protection as during the last 
decades there was an increase polluting emissions and an increase in the costs associated with the practices implemented to reduce these emissions. This change in the orientation of the Middle East and North Africa (MENA) region occurred during the intervention of the World Bank by highlighting the losses to be borne by countries that did not pay attention to the risks [in terms of quality and in terms of costs] resulting from the deterioration of the environmental component. This information is taken from the World Bank for the year 2010 .

In recent years, the phenomenon of climate change has become very remarkable in Algeria, given its recorded effects on the temperature and precipitation. Algeria is among the top fifty countries at high risk of climate change, with a vulnerability index of $7.63 \%$, because of its geographical position and climatic characteristics.

The national energy management agency mentioned that the degradation of the quality of the environment could be explained by several factors such as the harmful effects of greenhouse gas emissions (CO2, $\mathrm{SO} 2, \mathrm{NOx}$, etc.) resulting from production activities whose completion requires massive use of energy where $60 \%$ of greenhouse gas emissions in Algeria are generated by the energy sector.

In this context, certain measures have been implemented by a certain number of countries at the international level ensuring the reduction of greenhouse gas emissions by industrialized countries such as the ratification of the General Agreement in 1992 of the United Nations on the subject of climate change, followed by the birth of the Kyoto Protocol for the year 1997, and finally the Marrakech conventions established in 2001. Moreover, according to (Cole and Eliott, 2003) these various conventions were approved at the beginning of 2005 on the same subject, which is that of minimizing greenhouse gas emissions between 2008 and 2012 in a Rio-Kyoto climate regime.

Generally speaking, the relationship between the growth of economic activity and the performance of the environment has been treated and often discussed in several previous studies around the analysis of the environmental Kuznets curve (EKC) (at throughout the treatment of this article, EKC denotes the Kuznets Environmental Curve), (Beckerman, 1992; Panayotou, 2000; Dinda, 2004). These analyses have stimulated several economic analysts who have tried to verify that the advancement and economic performance of countries can lead to environmental degradation and that its stabilization depends on the 
achievement of a minimum degree of development, (Akbostanc1 et al., 2009; Richmond and Kaufmann, 2006; Dinda, 2005; List and Gallet, 1999; Khannaa and Plassmann, 2004; Verbeke and De Clercq, 2006).

With the environmental problems on an international scale, we are interested in this article to study the impact of air pollution on economic growth as part of an analysis of the EKC for the case of Algeria from the year 1980. The choice of Algeria is justified by the fact that it was classified among the economies of the region of North Africa known by a strong power of its economic growth, and this, by the implementing a panoply of structural adjustment programs.

It is based on elements that reflect the state of "environmental health", "air pollution", "water resources", "biodiversity and habitat", "natural resources", and "climate change" (Egli, 2004). The Environmental Performance Index (EPI) was created to assess, compare and improve the effectiveness of environmental policies (source: PopulationData.net). It was based on the following criteria: access to drinking water, sanitation, infant mortality, indoor pollution, particles in urban air, ozone in the air, nitrates in water, water consumption, protection of wilderness, protection of ecoregions, logging, overfishing, agricultural subsidies, energy efficiency, renewable energies, and $\mathrm{CO} 2$ emissions.

The approach for the remainder of this article will be as follows: the second section will focus on a review of the empirical literature. The third section shows the evolution of greenhouse gas emissions GHG in Algeria and renewable energy. An empirical investigation of the effect of pollution on economic growth in the context of the EKC in Algeria will be the subject of the forth section of this article. Finally, some conclusions and discussions will be the subject of the last section.

\section{Review of the Empirical Literature}

The availability of data relating to environmental degradation made it possible to econometrically test the hypothesis of the $\mathrm{EKC}$ in reduced form between the level of income per capita and various environmental indicators $(\mathrm{CO} 2$, $\mathrm{SO} 2, \mathrm{NOx}, \mathrm{SPM}$, deforestation, etc.). In this section, we review empirical studies relating to EKC while grouping them according to the methodology adopted (panel data, time series or cross-section). 
The empirical works that can be considered as the founders of the subject of EKC are numerous among others (Grossman and Krueger, 1993; 1995; Shafik and Bandyopadhyay, 1992; Cropper and Griffiths, 1994; Selden and Song, 1994; Antle and Heidebrink, 1995; Holtz-Eakin and Selden, 1995; Tucker, 1995; etc.) The common denominator between these works is that they used a polynomial regression model (in level or in logarithm) to study the existing relationship between certain indicators of environmental degradation and income per capita.

By analysing the empirical literature relating to this curve, we identified studies applied at the level of each country such as Sweden through the study of Lindmark (2002), Germany through the application carried out by Egli (2004) and France through the study of (Ang, 2007). According to the EKC curve hypothesis, the quality of the environment can improve only through long-term growth and development of the economy. The debates on this hypothesis have been justified by the diversity of the results identified at the level of several empirical applications in this field of research. According to an in-depth analysis of several works (Giles and Mosk, 2003; Chebbi, 2010; Panayotou, 1993), we note the presence of evidence showing that the Kuznets curve hypothesis is applicable. On the other hand, based on other empirical evidence extracted from previous works (Hettige et. al. 1999; Torras and Boyce, 1998; Cole and Eliott, 2003), we note the absence of concrete supports justifying the existence of such a hypothesis, by the "identification of a continually increasing or decreasing (monotonic) relationship between environmental degradation and economic growth". They worked in particular on Panel data. According to other authors (such as Lindmark, 2002), empirical applications addressing the relationship between environmental degradation and income level at the individual level can eliminate the problems caused by empirical cross-sectional evidence (Galeotti, 2007). The time-series analysis of the EKC hypothesis, at the individual level, can lead to the setting of adequate environmental policies for each country to the extent that the interaction between the variables can be better understood for this type of analysis.

Grossman and Krueger (1991) and Panayotou (1993) indicated an Inverted U-shaped relation between Economic Growth and Pollution by using Annual emissions of $\mathrm{NO} 2, \mathrm{SO} 2$, suspended particulate matter as dependent variables and GRP per capita and square, Population density, Industry Shares in GRP, and Trade Intensity as independent variables. Moomaw and Unruh (1997), Kaufmann et al. (1998), Dinda et al. (2000), Ozcan (2013), Chandran and 
Tang (2013), and Wang et al. (2011) found a U-shaped shift between Economic Growth and Pollution. Where the dependent variables used were annual emissions of $\mathrm{CO} 2, \mathrm{SO} 2$, suspended particulate matter and the independent variables were GRP per capita, Population growth, Spatial intensity of economic activity, Energy consumption, FDI, Transport energy consumption. For the N-shaped relation between economic growth and Pollution we found the studies of (Grossman and Krueger, 1991; Aslanidis and Xepapadeas, 2004; Sinha Babu and Datta, 2013). Park and Lee (2011) explored the relationship between economic growth and air pollution by using the annual panel data of sixteen metropolitan areas in Korea from 1990 to 2005. The results showed that GRP is negatively related to air pollution caused by $\mathrm{SO}_{2}$, failing to verify an inverted U-shaped nor N-shaped curves.

For the most up-to-date research studies, Phiri(2019) investigated relationships between economic growth, environmental degradation and business cycles in Eswatini for the period 1970 and 2014 by the NARDL model and found no EKC for Eswatini.

Khan et al. (2018) investigated the relationships between environmental regulation (ERG), FND, urban population growth, ENE, research and development and emissions and found no asymmetric cointegration between the variables. Khan et al. confirmed negative and significant linear relationships between ERG and emissions.

Ur Rahman et al. (2019) tested the pollution haven hypothesis for Pakistan for the period between 1975 and 2016 and confirmed a symmetric relationship between $\mathrm{F}$ inflow and emissions. Ur Rahman et al. confirmed the EKC hypothesis and pollution haven hypothesis for Pakistan.

Jiang et al. (2020) analyses the interaction between regional economic growth and air pollution in China and Korea. The results find that regional differences existed in the relationship between air pollution and economic growth in two countries. In both countries, an inverted U-shaped pattern was found in metropolitan areas while a U-shaped pattern of non-metropolitan areas.

Özden and Beşe (2021) analysed the relationship between economic growth and environmental degradation in Australia, by the using ARDL model. The results show that no causal relationship is found from GDP, square of GDP and ENE to CO2. The EKC hypothesis is not confirmed for Australia. 
Zhang (2021) conducts an empirical analysis on the long-standing relationship between $\mathrm{CO} 2$ emissions and income while controlling energy consumption, trade openness, and urbanization, by the using ARDL model. The results show that there is the $\mathrm{N}$-shaped relationship between $\mathrm{CO} 2$ emissions and real gross domestic product (GDP) per capita in the long run.

\section{Greenhouse Gas (GHG) and Renewable Energy in Algeria}

\subsection{Evolution of GHG}

Algeria is a party to the United Nations Framework Convention on Climate Change (UNFCCC). Two national inventories of greenhouse gas emissions and removals due to human activities are required for the years 1994 and 2000 (WB). The inventories provide estimates of anthropogenic greenhouse gases selected for the energy sectors; Industrial processes and product use; Agriculture, forestry and other land use (AFOLU); and waste.

Algeria has conducted two national emission inventories of greenhouse gas (GHG) emissions for the years 1994 and 2000. The inventory covered the direct six greenhouse gases $\left(\mathrm{CO}_{2}, \mathrm{CH}_{4}, \mathrm{~N}_{2} \mathrm{O}, \mathrm{SF}_{6}\right.$ and $\left.\mathrm{CFCs}\right)$ and indirect greenhouse gas precursors ( $\mathrm{NOx}, \mathrm{CO}, \mathrm{NMVOC}$ and $\mathrm{SO}_{2}$ ). The share of emissions of each greenhouse gas is illustrated in figure 1 (MATE, 2010).

In 2008, the overall GHG emissions totaling 121.31 MT eq. $\mathrm{CO}_{2}$. Per capita emissions are 4.1 T eq. $\mathrm{CO}_{2} /$ inhab/an. It was 3.1 in year 1990 . 
Figure 1: GHG emissions from the energy sector in 1994 and 2000

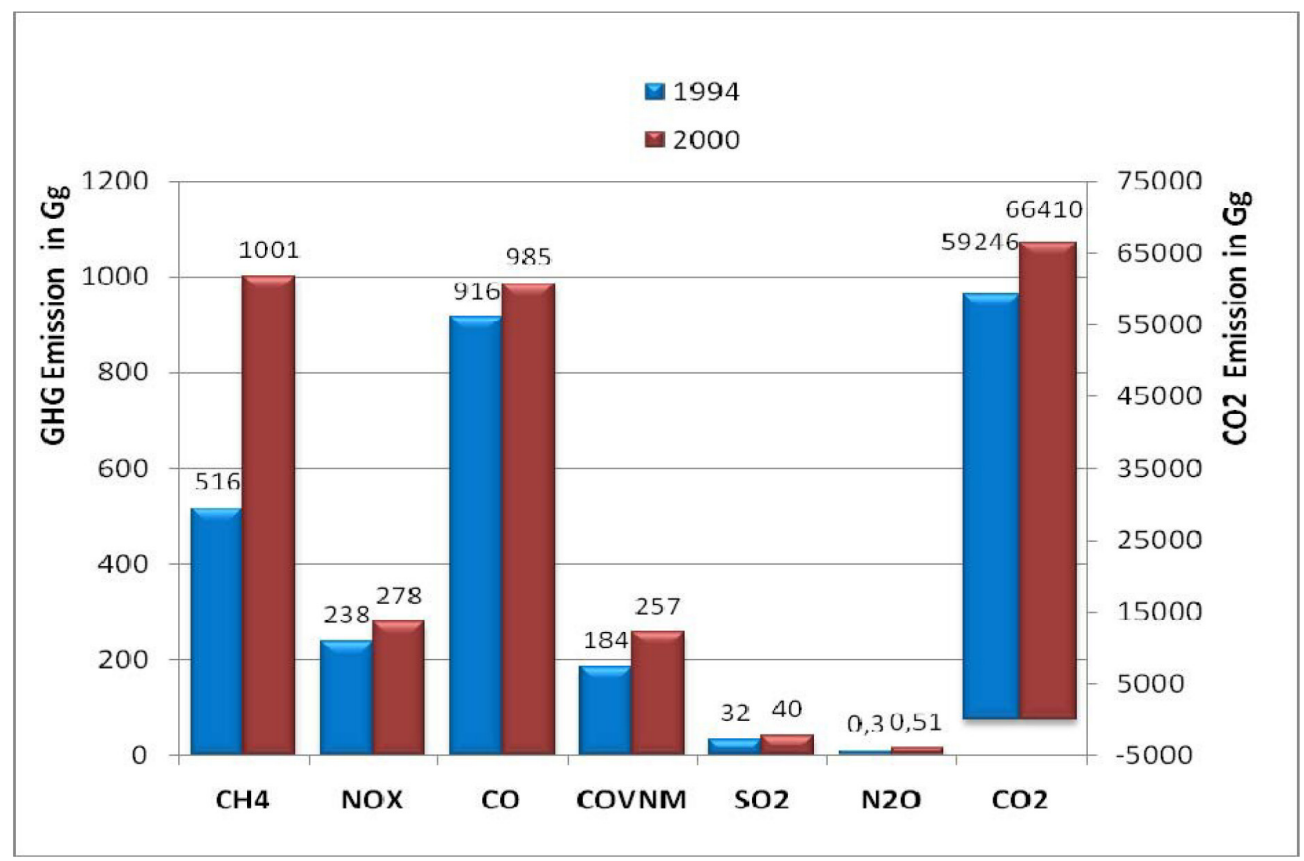

Source: MATE (2010)

Emissions from the energy sector on 2016 is dominated by CO2 at around $88 \%$ (Figure 2) with $168,659.36 \mathrm{Gg}$. This is especially in the combustion category where it represents overwhelming values at over $99 \%$. Next, $\mathrm{CH} 4$ with $11.8 \%$, with $22641.66 \mathrm{Gg}$, where the majority of these releases are due to fugitive emissions, and remains minimal for $\mathrm{N} 2 \mathrm{O}$ with less than $0.2 \%$, with $343.08 \mathrm{Gg}$ they are emitted mainly by the sector of energy industry and transport.

Figure 2: GHG emissions from the energy sector by type of gas in Algeria for 2016

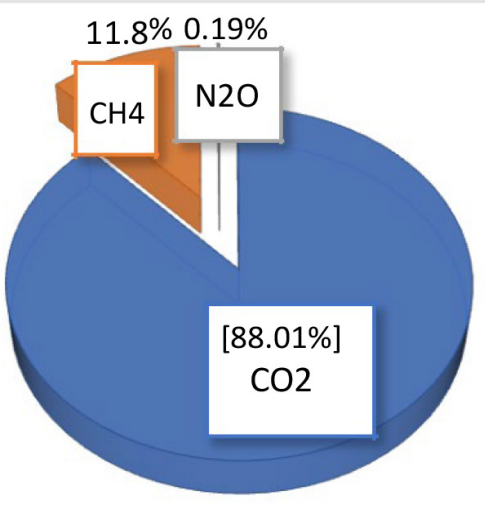


The world's countries emit vastly different amounts of heat-trapping gases into the atmosphere. By comparing the emission per habitant, Algeria is among important emitters from developing countries (Figure 3). In comparison, the average annual global emission of $\mathrm{CO} 2$ is $4.7 \mathrm{~T}$ /inhab., Qatar $55.4 \mathrm{~T}$ /inhab., UAE 31.1 T / inhab.,U.S. \$ $19.8 \mathrm{~T} /$ inhab, France $6.1 \mathrm{~T} /$ inhab., Lebanon 20.3 T/ inhab, Tunisia 2.4 T/ inhab. Morocco $1.5 \mathrm{~T} /$ inhab., and India $1.4 \mathrm{~T} /$ inhab. (World Bank Data).

Figure 3: Comparison of $\mathrm{CO} 2$ emissions per capita among other countries

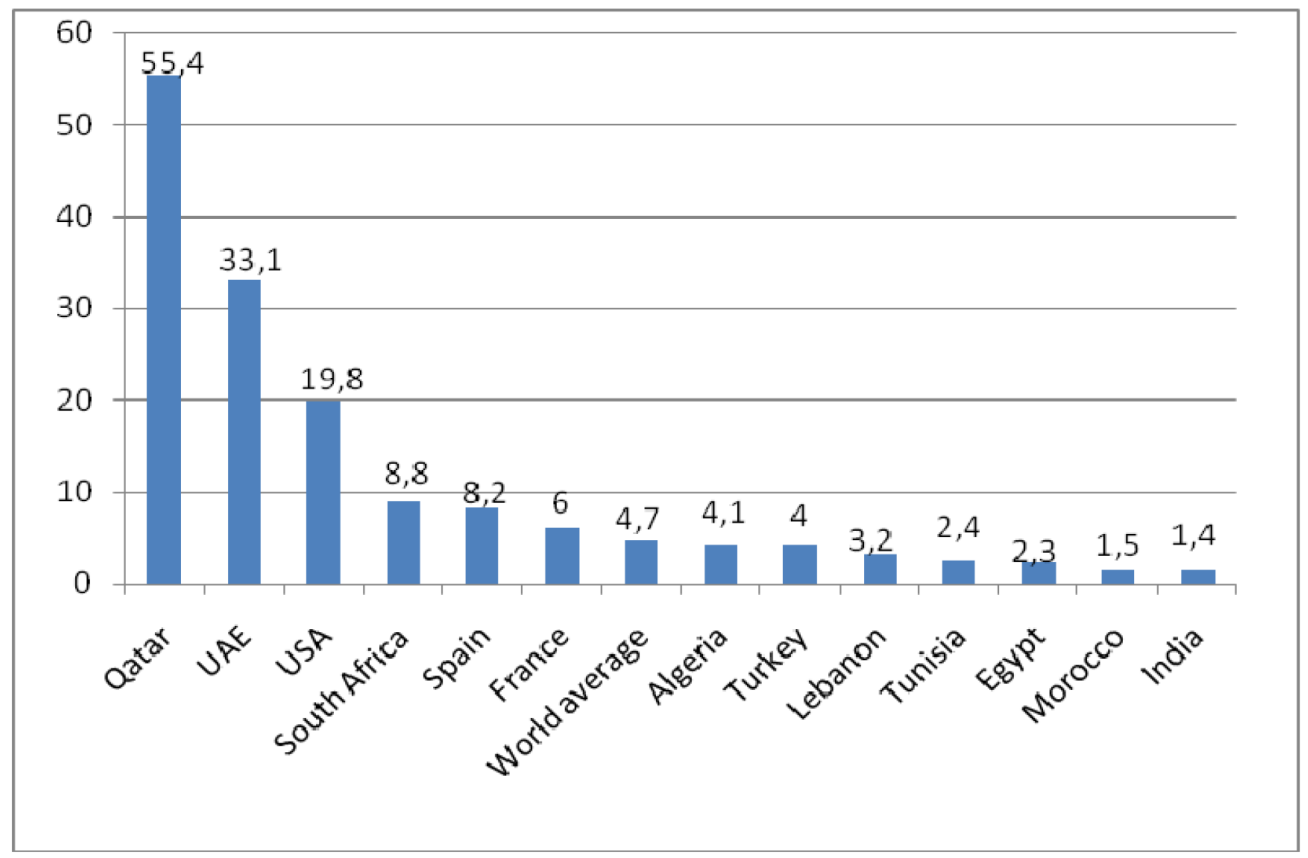

Source: World Bank Data

By activity, the energy sector (production and consumption), which is the source of highest emissions, about three-quarters of the total and this sector has the most important potential for mitigation measures (MATE, 2010).

With the exception of the industrial sector, whose activities are steadily declining, but all other sectors have been experiencing an increase in greenhouse gas emissions, and are continuing to grow due to the intense consumption of energy (Sahnoune et al., 2016). In fact, the contribution of the industrial sector to the GDP was estimated at 7\% in 2005 and $4.8 \%$ in 2012 (AFDB, 2013). The development of greenhouse gas emissions shows an average annual growth rate of 2.2\% (Sahnoune et al., 2016). During the period from 2001 to 2016, it 
is evident that the increase in the average annual energy consumption is in line with the growth rate. (Sahnoune et al., 2016).

\subsection{Renewable energy in Algeria}

However, not all these measures allow substantially reduction of the current level of GHG emissions. The estimated reduction impacted by these measures account for 10 to $12 \%$. The new development plan for renewable energy announced in early 2011 provides for the production of 22,000 MW of energy generated from renewable sources during the aforementioned period, in which 12,000 megawatts will be provided for the domestic demand for electricity and 10,000 megawatts are allocated for export (Ghezloun et al., 2015). This program aims to cover the domestic consumption of $40 \%$ of the electricity produced from renewable energy sources by 2030. This is in addition to wind energy, which is a relatively low source of energy. Several solar PV projects have been launched, as the government aims to reach $800 \mathrm{MW}$ by the end of 2020. Other projects with an annual capacity of $200 \mathrm{MW}$ will be completed during the period 2021-2030 (REEEP).

Despite the solar power stations that have been built so far in Algeria in order to exploit its high potential in the use of solar energy, they remain insufficient to this day compared to the increasing demand for energy. According to the 2013 Middle East and North Africa (MENA) Renewable Energy Status Report by REN21, installed capacity of photovoltaic (PV) power was 7.1 MW in 2010 and 25 MW in 2012 from Concentrated Solar Power (CSP) (Middle East and North Africa (MENA), RSR 2013).

\section{Methodology}

\subsection{Description of the data}

In this empirical investigation, the endogenous variable relating to economic growth is expressed as a function of real GDP per capita at constant price (in \$) (PGDP). We will introduce as independent variables: CO2 emissions per capita (PECO2), sulphate dioxide emissions per capita (PESO2) and nitrogen dioxide emissions per capita (PENOx); all the series will be transformed into natural al logarithm. 
Greenhouse gas emissions are the result of all actions and operations carried out by humans and are responsible for global warming and climate change. The choice of these types of pollutants is justified by their availability in a large number of countries, and they are the most appropriate indicators for measuring environmental degradation.

These polluting emissions contribute to direct and particularly unfortunate effects, namely, the increase in heat on the whole planet, a transformation resulting in the variation of precipitation translated by "more precipitation in high latitudes and less rain in most of subtropical lands", "atmospheric disturbances" [mainly caused by CO2 emissions], the lack of humidity leading to a significant increase in fires destroying natural environments (Egli, 2004).

$\mathrm{CO} 2$ is the primary cause of global warming. In adults, prodromes that improve the functioning of the inhalation and exhalation cycles may be aggravated by sulphur dioxide [SO2], a gas that can cause painful inflammation. In children, this pollutant causes problems and deterioration of lung function. NOx groups together two types of greenhouse gases relating to nitrogen monoxide NO and nitrogen dioxide $\mathrm{NO} 2$.

The variables to be used in this study are presented as annual series. For the variable relating to real GDP per capita, we focused on the database provided by the World Bank (2019) and the International Monetary Fund (IMF). For the series of greenhouse gas emissions, we used the database from Global Atmospheric Research (GAR).

The $\mathrm{CO} 2, \mathrm{SO} 2$ and $\mathrm{NOx}$ emissions are calculated according to a basic formula adopted by "the Global Atmospheric Research" including various sources responsible for the various greenhouse gas emissions. We relied on total CO2 emissions from the following sources: other energy industries, manufacturing and construction industries, road transport, rail transport, inland navigation, other means of transport, residential sectors, fugitive emissions from solid fuels, fugitive emissions from oil and gas, cement production, lime production, chemical production, metal production, use of solvents and other chemicals, and other soil emissions. For SO2 and NOx emissions, they are also generated by these same sources by adding: management of manure emissions and the combustion of agricultural waste. To calculate the emissions per capita, we divided the total emissions by the population. The population database was provided by the World Bank (2019) and by ERS International Macroeconomic Data Set (2019). 
In the context of our study (VAR modelling), where we will study the cointegration relationship between air pollution and economic growth, we will not be interested in the inclusion of other variables whose integration is fundamental at the level of growth models based in particular on instantaneous sectional analyses or on panel data, eor example: the intensity of trade liberalization, population density, intensity of economic activity, foreign direct investment, debt, etc. A more in-depth analysis on the subject of additional variables of the growth model is illustrated in the study of Dinda (2005).

Based on the determination of the vector autoregression (VAR), we will test in what follows the cointegration relation by the application of the Johansen procedure by applying the test of the statistical trace and the test of maximum likelihood (test of the maximum eigenvalue), (Johansen, 1995; Lardic and Mignon, 2002). This technique leads us to obtain two types of results: in the case of the absence of the long-term relation between the series, the determination of the direction of short-term causality is carried out based on differentiated series in the VAR model (first difference). However, obtaining a co-integrating relation between the series justifies the presence of a long-term relation where the causality tests are determined based on the error correction model (ECM). In a next step, we will express the error correction vectors (VECM). One such step consists in estimating the long-term parameters. Finally, a last step of this application will be devoted to a verification of the EKC hypothesis.

\subsection{Econometric model}

The EKC hypothesis comes from an empirical specification in reduced form. Therefore, it can be a consequence of more than one structural relationship, since it is an empirical phenomenon. Therefore, what is analyzed is the apparent relationship between per capita income and environmental degradation (Piaggio and Padilla, 2012; Piaggio et al., 2017). Following previous works, the empirical model in a reduced form shown by Piaggio and Padilla (2012) to relate environmental degradation and the level of economic activity is the following:

$$
E_{t}=\alpha_{t}+\beta_{1} Y_{t}+\beta_{2} Y_{t}^{2}+\beta_{3} Y_{t}^{3}+\varepsilon_{t}
$$

where $\mathrm{E}$ is an indicator of per capita environmental degradation and $\mathrm{Y}$ is per capita income. The subscript $\mathrm{t}=1, \ldots, \mathrm{T}$ indicates the time period and $\varepsilon$ is the random shock. 
At the level of this second equation will be presented the Pollutant emissions (PE) according to the GDP within the framework of the EKC:

$$
\ln P E_{t}=\alpha_{0}+\beta_{1} \ln P G D P_{t}+\beta_{2} \ln P G D P_{t}^{2}+\beta_{3} \ln P G D P_{t}^{3}+\varepsilon_{t}
$$

With

$$
\ln P E_{t} \Rightarrow\left\{\begin{array}{l}
\ln \mathrm{PECO}_{2} \\
\ln \mathrm{PESO}_{2} \\
\ln \mathrm{PENO} \mathrm{O}_{x}
\end{array}\right.
$$

Figure 2: Possible behaviours of the relationship between environmental degradation and level of economic activity

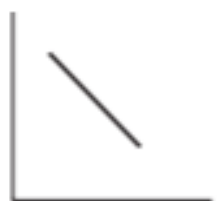

(a)

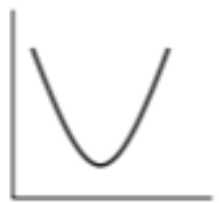

(d)

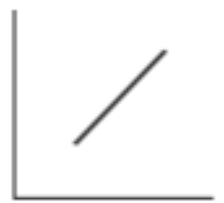

(b)

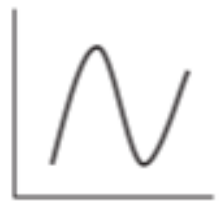

(e)

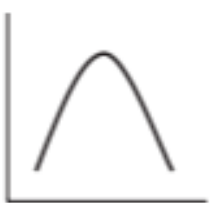

(c)

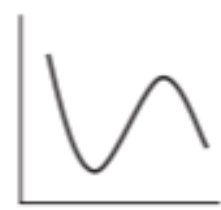

(f)

Source: Ekins (1997) cited in Díaz (2007, pp. 141)

Based on Figure 2, which represents the level of economic activity on the abscissa axis and the level of environmental degradation on the ordinate axis, these could be the different behaviors of the relationship between both variables defined in the equation (one):

(a) Decreasing linear relationship, higher levels of economic activity would imply lower levels of environmental degradation. The coefficients in equation (1) should meet the following restrictions: $\beta 1<0, \beta 2=\beta 3=0$.

(b) Increasing linear relationship, higher levels of economic activity lead to greater environmental degradation, $\beta 1>0, \beta 2=\beta 3=0$.

(c) Quadratic relationship in the shape of an inverted U, at levels of low economic activity; growth in this means an increase in environmental 
degradation until a critical point is reached from which higher levels of economic activity reduce environmental degradation. $\beta 1>0, \beta 2<0, \beta 3=0$. This would be the relationship advocated by the CKA hypothesis.

(d) Quadratic U-shaped relationship: symmetric explanation to the previous one. $\beta 1<0, \beta 2>0, \beta 3=0$.

(e) Cubic relationship in the form of $\mathrm{N}$, the same behaviour as in the case of the inverted-U shape, but another critical point appears from which the growth of economic activity again leads to greater environmental degradation. $\beta 1>0$, $\beta 2<0, \beta 3>0$.

(f) Cubic relationship in the form of an inverted $\mathrm{N}$, symmetric explanation to the previous one. $\beta 1<0, \beta 2>0, \beta 3<0$.

Although it is not contemplated in Figure 1, it would also be possible that the variables were not correlated, $\beta 1=\beta 2=\beta 3=0$.

It is important to mention that the general model has been shown. In each study, details are made on the model to be estimated, whether levels or logarithms are used, as well as the estimation method applied. There are many indicators of environmental degradation, so each study specifies which ones to use and the explanatory variables that may be relevant for the estimation beyond the level of economic activity. These indicators of environmental degradation or pressure are usually defined in terms of emissions or other variables, such as concentrations or per capita energy consumption, and the level of economic activity is usually measured with income per capita.

Before proceeding with the interpretation of the results of the stationary tests, it is necessary to establish the order (p) of the VAR process for the different relations. We will then retain the VAR process, including the two information criteria of Akaike (AIC), Schwarz (SIC) and lowest log-likelihood (LV).

\section{Results and Discussion}

Before proceeding with the various cointegration tests in order to detect the presence or not of a long-term relationship between the GDP series (in natural logarithm) and the different series of polluting emissions (in natural logarithm), it is a question of firstly, to verify the stationary of these series in 
first difference. The results show us that all the series of the model are nonstationary in level so they have a unit root at this level. On the other hand, the ADF, PP and KPSS tests show us that the hypothesis H1 should be accepted as a first difference, which proves that it is about series I (0) (integrated of order $0)$ to this level.

In this framework, we conclude that the different series are I (1) (integrated of order (1)) in level. After having verified the stationary of the variables in first difference, we can therefore proceed to the application of the cointegration tests for the case of Algeria by the means of the Johansen procedure following two specific maximum likelihood tests, namely, the test of the statistics of the trace and the test of the maximum eigenvalue in order to determine the number of cointegration vectors reflecting in this sense the number of relations over the long period. The results of the long-term tests will be illustrated in the series of the following tables: table (1-a), table (1-c) (in Appendix) and table (1-b).

Table 1-b: Results of Johansen cointegration tests (1995) for SO2 emissions

\begin{tabular}{|l|c|c|}
\hline \multirow{2}{*}{ Hypotheses } & \multicolumn{2}{|c|}{ H0/H1 } \\
\cline { 2 - 3 } Cointegration Tests & $\boldsymbol{r}=\mathbf{0} / \boldsymbol{r} \geq \mathbf{1}$ & $\boldsymbol{r} \leq \mathbf{1} / \boldsymbol{r}=\mathbf{2}$ \\
\hline Trace statistics $\lambda$ trace & $123.66^{* *}$ & $39.891^{* *}$ \\
\cline { 2 - 3 } Critical value $(\mathrm{CV})$ & 48.794 & 30.108 \\
\hline Probability & 0.0000 & 0.0021 \\
\hline $\begin{array}{l}\text { Statistics of MPV } \lambda \text { max } \\
\text { Critical value (CV) }\end{array}$ & $78.974^{* *}$ & $27.021^{* *}$ \\
\hline Probability & 26.854 & 20.984 \\
\hline Cointegration Tests & 0.0000 & 0.0063 \\
\hline Trace statistics $\lambda$ trace & $\boldsymbol{r} \leq \mathbf{2} / \boldsymbol{r}=\mathbf{3}$ & $\boldsymbol{r} \leq 3 / \boldsymbol{r}=\mathbf{4}$ \\
\hline Critical value $(\mathrm{CV})$ & 16.084 & 0.7845 \\
\hline Probability & 16.398 & 4.2317 \\
\hline Statistics of MPV $\lambda$ max & 0.0532 & 0.4315 \\
\hline Critical value $(\mathrm{CV})$ & $15.853^{* *}$ & 0.7586 \\
\hline Probability & 15.153 & 4.1538 \\
\hline
\end{tabular}


Following the implementation of a sequential structure, the two tests on which the Johansen procedure were based on the same series of hypotheses according to the same principle of definition of these hypotheses while passing from a number of cointegration vectors equal to 0 to a number equal to 4 . Indeed, the first null hypothesis $\mathrm{H} 0$ is defined by the absence of co-integrating vectors $(\mathrm{r}=$ 0 ) against an alternative hypothesis $\mathrm{H} 1$ relating to the presence of at least one co-integrating vector $(r \geq 1)$.

The latter will be accepted if the statistic of the trace or the statistic of the maximum eigenvalue (respectively $\lambda_{\text {trace }}$ and $\lambda_{\text {max }}$ ) is greater than the critical values obtained. For a second level of estimation, the null hypothesis H0 is defined by the existence of a single co-integrating vector $(\mathrm{r} \leq 1)$ against an alternative hypothesis $\mathrm{H} 1$ relating to the presence of at least two co-integrating vectors $(r=2)$ (the same approach will be applied for the assumptions of the third and fourth estimates). The optimal number of lags ( $p$ ) chosen and established for each cointegration relation was selected according to the information criteria of AIC and SIC, the results of which are detailed in table (2) (we noticed d 'after these results that the optimal number of delays is equal to 4, see table (2) (Appendix). It should be noted that according to Torras and Boyce (1998) the Johansen approach in our study was based in particular on the integration of the constant The set of tables relating to the results of the cointegration tests between the GDP series and the polluting emissions series for Algeria show that the null hypothesis $\mathrm{H} 0$ was rejected at the level of 5\% for the three cases according to the statistical test of the trace and the test of the maximum eigenvalue.

The number of cointegration vectors for the case of Algeria for the different relations (PGDP / PECO2 - PGDP / PESO2 - PGDP / PENOx) is evaluated at 2 (two long-term relations). The results of the equations relating to the IC vectors and the adjustment coefficients determined by writing the vector of the error correction model (VECM) can be found in Table (2). 
With the cointegration, equations are as follows:

$$
\begin{aligned}
& \operatorname{lnPECO}{ }_{2}=-15.9748 \operatorname{lnPGDP} P_{t}+4.103 \operatorname{lnPGDP_{t}^{2}}-0.3107 \ln P G D P_{t}^{3} \\
& (-8.9686 * * *) \\
& \text { (8.1046***) } \\
& (-7.8943 * * *) \\
& \ln \mathrm{PESO}_{2}=-29.1107 \ln \mathrm{PGDP}_{t}+8.0183 \ln P G D P_{t}^{2}-0.6281 \ln P G D P_{t}^{3} \\
& (-6.8892 * * *) \\
& (6.9463 * * *) \\
& (-6.9784 * * *) \\
& \ln P E N O_{x}=-7.3172 \ln P G D P_{t}+1.6108 \ln P G D P_{t}^{2}-0.1371 \ln P G D P_{t}^{3} \\
& (-9.2837 * * *) \quad(7.8636 * * *) \quad(-7.5185 * * *)
\end{aligned}
$$

The results of the series correlation test (LM) tell us that we accept the hypothesis $\mathrm{H} 0$ for the first two equations (respectively at the 5\% and $1 \%$ threshold) and we reject it for the last equation. Moreover, the second Joint Jarque-Bera test shows that the $\mathrm{H} 0$ hypothesis is accepted that for the first equation at the threshold of $1 \%$ while for the last two equations the residuals are not Gaussian.

Moreover, at the level of table (2) illustrating the cointegration vectors, we notice that all the coefficients of the vectors of the long-term relation are significant. The signs of the coefficients of the CI vectors (cointegration) show us a relation having the form of an inverted $\mathrm{N}$ for the three study cases: PGDP / PECO 2 - PGDP / PESO 2 - PGDP / PENOx $(\theta 1<0, \theta 2>0$ and $\theta 3<0)$. On the other hand, by solving the equations of this model (determination of the roots) and according to the diagram of the shape of the EKC at the level of the list of illustrated below, we observe a relation having the form of a U-reversed according to two specific phases, the first of which is characterized by an increase in emissions followed by another descending phase where the quality of the environment has improved to a certain level of GDP for the case of $\mathrm{SO} 2$ and NOx emissions while for $\mathrm{CO} 2$ emissions, there is a long increasing phase (32 years) followed by a decrease in emission levels for the last five observations of this study.

In the same framework of analysis, and following the observation of these representations for the case of Algeria, it is concluded that the EKC is confirmed for the case of $\mathrm{SO} 2$ emissions per capita and NOx per capita. Also for the case of carbonic emissions (CO2), this hypothesis of the EKC is confirmed in our study but we cannot currently estimate the nature of the evolution of these 
emissions (increase or decrease) after the year 2017. In this case, framework, it is possible that previous studies on the relationship of $\mathrm{CO} 2$ emissions and economic growth in Algeria could clarify the trend of the evolution of the pace of the EKC in the coming period.

Indeed, for the first case corresponding to the relationship between carbon emissions and the achieved level of gross domestic product, we noted that the turning point of EKC-PECO2 from which a decrease in the level of these emissions was observed and relative in a more or less precise way to a level of real GDP per capita estimated at \$2723.6, i.e. the equivalent of \$ 6754.7 (in purchasing power parity (PPP) at constant 2010 price). Such a level of GDP was achieved in Algeria in 2015. For the case of sulphate dioxide emissions, with the attainment of an approximate level of $\$ 1745.8$ relative to an amount of $\$ 4278.6$ (in PPP at the constant price of 2010 ), SO2 emissions begin to decrease where the EKC begins a second downward phase defined by an attenuation of environmental degradation of which this ceiling defines the turning point in EKC-PESO2.

It was in the early 1990s that Algeria's GDP grew to this level. Finally, for the case of nitrogen emissions, the level of GDP per capita at the constant price reached at which these emissions start to decrease in the EKC-PENOx is estimated at approximately $\$ 1700.3$ and which is, in a comparison, similar to \$4226.5 (PPP at constant price of 2010).

It was in the early 1990s that Algeria succeeded in controlling its emissions and reducing them with the aim of achieving sustainable development strategies. The diagram of the EKC respectively for the case of $\mathrm{SO} 2$ and NOx emissions per capita show that Algeria managed to control the levels of these three air pollutants at the beginning of the 1990s, in particular in 1990 for nitrogen, in 1991 for sulphate dioxide emissions and in 1996 for carbon emissions.

In the error correction model, the parameters ai obtained measure the speed of adjustment towards the long-term equilibrium level. By analyzing the results in table (2) all the parameters are negative signs and statistically significant at the $5 \%$ threshold $(-0.1794)$ for the case of $\mathrm{CO} 2$ emissions and at the $1 \%$ threshold for the other two pollutants (-0.4578) and (-0.1796) respectively for $\mathrm{SO} 2$ emissions per capita and NOx per capita which is due in particular to the presence of an error correction process for Algeria. 
Following the observation of the results of the VECM, we conclude that taking into account the error correction technique for the case of Algeria is essential because a change following a variation towards equilibrium long-term will have a sufficiently large (significant) effect on the growth and evolution of polluting emissions.

The specificity of the long-term equilibrium adjustment structure has differed from one relationship to another. The adjustment speeds for the case of Algeria over a period of one year were evaluated respectively at $17.94 \%, 45.78 \%$ and $17.96 \%$, where they take respectively 5.42 years, 2.30 years and 5.49 years to find themselves in position of equilibrium during a shock of an innovation having certain effects on the structure of the relationship between the variables.

In order to identify the nature of the relationship between economic growth and air pollution, a new principle for the causal relationship was created and generalized by Granger (1969) known as the causal relationship in the sense by Granger. In other words, if we have two series $Y_{t}$ and $X_{t}$ this causality test allows us to know if the series $Y_{t}$ causes in the sense of Granger the series $X_{t}$ and to show the degree of capacity of the past values of $X_{t}$ to explain the value current of $Y t$, (in our case study: $Y_{t}$ designates the series of real GDP per capita and $X_{t}$ represents the series of polluting emissions. The Granger test was applied in this case to the first difference of each series.).

In our case study, $\mathrm{Y}_{t}$ denotes real GDP per capita and $\mathrm{X}_{\mathrm{t}}$ denotes the series of polluting emissions.

The application of the Granger procedure for identifying the direction of longterm causation will be carried out through the weak exogeneity test to detect the direction of long-term causation based on the following hypothesis:

$$
T_{i}: H_{0}: \alpha_{i}=0 \Rightarrow \text { with }, i=1,2
$$

We define $\alpha \mathrm{i}$ by the adjustment coefficients in the error correction model (ECM), Ti relate to the tests of weak exogeneity of economic growth and polluting emissions $(i=1.2)$, insofar as emissions include per capita $\mathrm{CO}$, per capita $\mathrm{SO} 2$ and per capita $\mathrm{NOx}$. 


\section{Conclusion and Policy Implications}

In this paper, we have studied the relationship between economic growth and environmental degradation generated by greenhouse gas emissions, where we have based ourselves on the analysis of the EKC for the case of Algeria on the period $1980-2017$ / $1980-2015$ according to a VAR model.

In this sense and with the aim of studying the cointegration relationship between the series, our analysis was based on an econometric approach following chronological data. The econometric results show that the hypothesis of the EKC is confirmed for the case of the three relations following the shape of an U-inverted at different income levels although the econometric results of the estimates of the cointegration relation indicated a relation having a form of a $\mathrm{N}$-inverted.

Indeed, the amount of GDP at which $\mathrm{CO} 2$ emissions begin to decrease is estimated at approximately $\$ 2723.6$ or the equivalent of $\$ 6754.7$ (in purchasing power parity (PPP) at constant price of 2010). We cannot currently estimate the nature of the evolution of these emissions (increase or decrease) after the year 2017. In this context, it is possible that previous studies on the relationship of $\mathrm{CO} 2$ emissions and economic growth in Algeria could specify the evolution of the pace of the EKC in the coming period.

The turning point of EKC-PESO2 according to which Algeria was able to control its SO2 emissions was estimated at $\$ 1745.8$ relative to an amount of $\$ 4278.6$ (in purchasing power parity (PPP) at the constant price of 2010). For the case of NOx emissions per capita, a further decreasing phase was recorded at the level of EKC-PENOx when the real GDP per capita reached a level of \$ 1700.3 , which is in a comparison, similar to $\$ 4226.5$.

These three levels of GDP were reached in the early 2000s (2000, 2001 and 2006). In the case of sulphate dioxide emissions, the results obtained in this empirical investigation are not surprising insofar as, at a certain maximum threshold of GDP, these emissions attenuate over time. Compared with CO2 emissions, which have a detrimental effect on the world population, SO2 emissions only have a direct influence on the regional population. In addition, economic activity in Algeria is based in particular on sources of polluting emissions, which are quite limited and on investments with a high capacity to control the concentration of products harmful to the environment. 
To generalize, the encouragement of the Algerian government, by promoting an institutional and regulatory framework favourable to the protection of the quality of the environment and the control of energy consumption, was the priority of the 1990s in the fight against global warming of the planet, which explains in particular the second decreasing phase of EKC-PESO2 and EKCPENOx. Such a priority has been reflected in the adoption of a proactive policy to control energy consumption (one of the origins of air pollution) and by the promotion of renewable energy sources in a context of improvement and increase in economic activity.

Regarding EKC-PECO2, it was at the beginning of 2006 that Algeria was able to control $\mathrm{CO} 2$ emissions and was considered a good justification for the efforts focused by the Algerian authorities throughout the years 1990 and 2000 .

In the Middle East and North Africa (MENA) region, carbon emissions from electricity generation are expected to increase. It is estimated that in 2030, CO2 emissions from energy use will drop from $34 \%$ to $36 \%$.

As part of the management of greenhouse gas emissions and the fight against their potential and harmful effects on global climate change, Algeria opts for a strategy based on several well-defined actions: i- prevent, eliminate and limit 'emission of harmful gases into the atmosphere; ii- identify and monitor sectors and regions likely to experience serious air pollution problems; iii- carry out energy inventories in order to save energy and limit the resulting pollution, iv- establish and develop balanced management of air quality. These points are developed according to the national strategy within the framework of the environment and sustainable development in Algeria.

Algeria reiterated in Amman (Jordan) its commitment to reduce its greenhouse gas (GHG) emissions by 2020 - 2030 under the Paris agreement on the climate adopted in 2015, which aims to maintain the rise in the Earth's average temperature below 2 degrees Celsius. Participating in the sixth meeting of the steering committee of the "Climasouth" project (European project on climate change), held on March 29 and 30 in the Jordanian capital, the Algerian focal point for the "Climasouth" project recalled that Algeria, as such, submitted, in 2015, its national contribution planning to reduce between $7 \%$ and $22 \%$ its GHG emissions, told APS Ms. Ghalia Benzouiche, Deputy Director of the Environment and Sustainable Development at the Ministry of Foreign Affairs. 
According to the Algerian contribution, Algeria is committed to reducing its greenhouse gas (GHG) emissions by 7\% from 2020 by using national means through actions aimed at operating an energy transition and economic diversification. However, this reduction in GHGs could reach 22\% if Algeria receives the necessary international support by 2030 .

To complete the analysis of the cointegration results and to interpret them economically, we applied the Granger causality test (weak exogeneity test) on the error correction model to determine the causal directions between economic growth and environmental degradation. In this sense, we identify a long-term unidirectional causality going from income to $\mathrm{CO} 2$ emissions, head share (this is also the case for SO2 and NOx emissions). This means that any increase in GDP leading to an increase in pollutant emissions, as long as the adoption of policies and strategies to reduce the concentration of emissions and the use of low-emission investments will not harm economic growth in Algeria. In this context, the implementation of a range of measures aimed at protecting the quality of the Algerian environment and controlling energy consumption should be the primary priorities in the context of sustainable development and the strengthening of the growth of long-term in Algeria.

\section{REFERENCES}

[1] AFDB. (2013). African Development Bank, Climate Change Action Plan (CCAP), 2013.

[2] Akbostancı, E., Türüt-Aşık, S., \& Tunç, G. İ. (2009). The relationship between income and environment in Turkey: Is there an environmental Kuznets curve? Energy Policy, 37(3), 861 - 867. https://doi.org/10.1016/j.enpol.2008.09.088

[3] Ang, J. B. (2007). CO2 emissions, energy consumption, and output in France. Energy Policy, 35(10), 4772 - 4778. https://doi.org/10.1016/j.enpol.2007.03.032

[4] Antle, J. M., \& Heidebrink, G. (1995). Environment and Development: Theory and International Evidence. Economic Development and Cultural Change, 43(3), 603 625. https://doi.org/10.1086/452171

[5] Aslanidis, N., \& Xepapadeas, A. S. (2004). 'Inverted-V-Shaped' \& Smooth 'N-Shaped' Pollution-Income Paths. Working Papers 0405, University of Crete.

[6] Beckerman, W. (1992). Economic growth and the environment: Whose growth? whose environment? World Development, 20(4), 481 - 496. https://doi.org/10.1016/0305750x(92)90038-w 
[7] CDER. 2015. New National Energy Efficiency Program (2016 - 2030). Available at: http://portail.cder.dz/spip.php?article4445

[8] Chandran, V. G. R., \& Tang, C. F. (2013). The impacts of transport energy consumption, foreign direct investment and income on $\mathrm{CO} 2$ emissions in ASEAN-5 economies. Renewable and Sustainable Energy Reviews, 24, 445 - 453. https://doi.org/10.1016/j. rser.2013.03.054

[9] Chebbi, H. E. (2010). Long and Short-Run Linkages Between Economic Growth, Energy Consumption and CO2Emissions in Tunisia. Middle East Development Journal, 2(1), 139 - 158. https://doi.org/10.1142/s1793812010000186

[10] Cole, M. A., \& Elliott, R. J. R. (2003). Determining the trade-environment composition effect: the role of capital, labor and environmental regulations. Journal of Environmental Economics and Management, 46(3), 363 - 383. https://doi.org/10.1016/ s0095-0696(03)00021-4

[11] Cropper, M. \& Griffiths, C. (1994). The interaction of populations, growth and environmental quality. American Economic Review, 84(2), 250 - 254.

[12] Díaz, M. R. (2007). Estudio empírico de las causas subyacentes en la Hipótesis de la Curva de Kuznets Ambiental: Influencia de factores exógenos y análisis de descomposición (Unpublished doctoral dissertation or master's thesis). Universidad de Santiago de Compostela.

[13] Dinda, S., Coondoo, D., \& Pal, M. (2000). Air quality and economic growth: an empirical study. Ecological Economics, 34(3), 409 - 423. https://doi.org/10.1016/ s0921-8009(00)00179-8

[14] Dinda, S. (2004). Environmental Kuznets Curve Hypothesis: A Survey. Ecological Economics, 49(4), 431 - 455. https://doi.org/10.1016/j.ecolecon.2004.02.011

[15] Dinda, S. (2005). Does Environment link to growth? Economic Research Unit, Indian Statistical Institute, Kolkata-108.

[16] EDGAR. (2017). Emission Database for Global Atmospheric Research (EDGAR). Available at: http://edgar.jrc.ec.europa.eu/; Sum.

[17] Egli, H. (2004). The environmental Kuznets curve-evidence from time series data for Germany. Working Paper Series 04 - 33, Institute of Economic Research.

[18] Galeotti, M. (2007). Economic growth and the quality of the environment: taking stock. Environment, Development and Sustainability, 9(4), 427 - 454. https://doi. org/10.1007/s10668-006-9030-y

[19] Ghezloun, A., Saidane, A., Oucher, N., \& Merabet, H. (2015). Actual Case of Energy Strategy In Algeria and Tunisia. Energy Procedia, 74, 1561 - 1570. https://doi. org/10.1016/j.egypro.2015.07.720

[20] Giles, D. E., \& Mosk, C. (2003). Ruminant eructation and a long-run environmental Kuznets curve for enteric methane in New Zealand: Conventional and fuzzy regression. Econometrics Working Paper, 306. 
[21] Grossman, G. M., \& Krueger, A.B. (1991). Environmental Impacts of a North American Free Trade Agreement. NBER Working Paper No. 3914, National Bureau of Economic Research.

[22] Grossman, G. M., \& Krueger, A. B. (1993). Environmental Impacts of a North American Free Trade Agreement. In: Garber, P. (Ed.), The U.S.-Mexico Free Trade Agreement. MIT Press, Cambridge, pp. 13 - 56.

[23] Grossman, G. M., \& Krueger, A. B. (1995). Economic growth and the environment. Quarterly Journal of Economics, 110(2), 253 - 377. https://doi.org/10.2307/2118443

[24] Hettige, H., Mani, M., \& Wheeler, D. (1999). Industrial pollution in economic development: Kuznets revisited. World Bank Discussion Papers 402.

[25] Holtz-Eakin, D., \& Selden, T. M. (1995). Stoking the fires? CO2 emissions and economic growth. Journal of Public Economics, 57(1), 85 - 101. https://doi.org/10.1016/00472727(94)01449-x

[26] Jiang, M., Kim, E., \& Woo, Y. (2020). The Relationship between Economic Growth and Air Pollution-A Regional Comparison between China and South Korea. International Journal of Environmental Research and Public Health, 17(8), 2761. https://doi.org/10.3390/ijerph17082761

[27] Johansen, S. (1995). Likelihood-Based Inference in Cointegrated Vector Autoregressive Models. https://doi.org/10.1093/0198774508.001.0001

[28] Kaufmann, R. K., Davidsdottir, B., Garnham, S., \& Pauly, P. (1998). The determinants of atmospheric SO2 concentrations: reconsidering the environmental Kuznets curve. Ecological Economics, 25(2), 209 - 220. https://doi.org/10.1016/s09218009(97)00181-x

[29] Khan, Z., Sisi, Z., \& Siqun, Y. (2018). Environmental regulations an option: Asymmetry effect of environmental regulations on carbon emissions using non-linear ARDL. Energy Sources, Part A: Recovery, Utilization, and Environmental Effects, 41(2), 137 - 155. https://doi.org/10.1080/15567036.2018.1504145

[30] Khanna, N., \& Plassmann, F. (2004). The demand for environmental quality and the environmental Kuznets Curve hypothesis. Ecological Economics, 51(3-4), 225 - 236. https://doi.org/10.1016/j.ecolecon.2004.06.005

[31] Lardic, S., \& Mignon, V.(2002). Économétrie des séries temporelles macroéconomiques et financières. Paris: Economica.

[32] Lindmark, M. (2002). An EKC-pattern in historical perspective: carbon dioxide emissions, technology, fuel prices and growth in Sweden $1870-1997$. Ecological Economics, 42(1-2), 333 - 347. https://doi.org/10.1016/s0921-8009(02)00108-8

[33] List, J. A., \& Gallet, C. A. (1999). The environmental Kuznets curve: does one size fit all? Ecological Economics, 31(3), 409 - 423. https://doi.org/10.1016/s09218009(99)00064-6 
[34] Ministère de l'Aménagement du Territoire et de l'environnement (MATE). (2010). Seconde communication nationale de l'Algérie sur les changements climatiques à la CCNUCC, projet GEF -PNUD 00039149, 2010, Algiers.

[35] Middle East and North Africa (MENA). (2013). Renewable status report, 2013. Available at: http://www.ren21.net/portals/0/documents/activities/regional\%20 reports/MiddleEastandNorthAfrica (MENA)2013_lowres.pdf.

[36] Moomaw, W.R., \& Unruh, G.C. (1997). Are environmental Kuznets curves misleading us? The case of CO2 emissions. Environment and Development Economics, 2(4), 451 - 463. https://doi.org/10.1017/s1355770x97000247

[37] Ozcan, B. (2013). The nexus between carbon emissions, energy consumption and economic growth in Middle East countries: A panel data analysis. Energy Policy, 62, 1138 - 1147. https://doi.org/10.1016/j.enpol.2013.07.016

[38] Özden, C., \& Beşe, E. (2021). Environmental Kuznets Curve (EKC) in Australia: Evidence from Nonlinear ARDL Model with a Structural Break. Polish Journal of Environmental Studies, 30(3), 2245 - 2254. https://doi.org/10.15244/pjoes/127555

[39] Panayotou, T. (1993). Empirical tests and policy analysis of environmental degradation at different stages of economic development. Working Paper 38.

[40] Panayotou, T. (2000). Economic growth and the environment. CID Working Paper, 56.

[41] Park, S., \& Lee, Y. (2011). Regional model of EKC for air pollution: Evidence from the Republic of Korea. Energy Policy, 39(10), 5840 - 5849. https://doi.org/10.1016/j. enpol.2011.06.028

[42] Perroux, F. (1991). L'économie du XXe siècle. Grenoble: Presses Universitaires de Grenoble.

[43] Phiri, A. (2019). Economic growth, Environmental degradation and business cycles in Eswatini. Munich Personal Repec Archive, 94993.

[44] Piaggio, M., \& Padilla, E. (2012). CO2 emissions and economic activity: Heterogeneity across countries and non-stationary series. Energy Policy, 46, 370 - 381. https://doi. org/10.1016/j.enpol.2012.03.074

[45] Piaggio, M., Padilla, E., \& Román, C. (2017). The long-term relationship between CO 2 emissions and economic activity in a small open economy: Uruguay $1882-2010$. Energy Economics, 65, 271 - 282. https://doi.org/10.1016/j.eneco.2017.04.014

[46] Richmond, A. K., \& Kaufmann, R. K. (2006). Is there a turning point in the relationship between income and energy use and/or carbon emissions? Ecological Economics, 56(2), 176 - 189. https://doi.org/10.1016/j.ecolecon.2005.01.011

[47] Sahnoune, F., Belhamel, M., \& Zelmat, M. (2016). Algerian energy policy and potential to reducing greenhouse gas emissions, Energy Sources, Part B: Economics, Planning, and Policy, 11(12), 1118 - 1127, https://doi.org/10.1080/15567249.2014.936537 
[48] Selden, T. M., \& Song, D. (1994). Environmental Quality and Development: Is There a Kuznets Curve for Air Pollution Emissions? Journal of Environmental Economics and Management, 27(2), 147 - 162. https://doi.org/10.1006/jeem.1994.1031

[49] Shafik, N., \& Bandyopadhyay, S. (1992). Economic Growth and Environmental Quality: Time Series and Cross-Country Evidence. Background Paper for the World Development Report 1992, Washington DC: The World Bank.

[50] Sinha Babu, S., \& Datta, S. K. (2013). The relevance of environmental Kuznets curve $(\mathrm{EKC})$ in a framework of broad-based environmental degradation and modified measure of growth - a pooled data analysis. International Journal of Sustainable Development \& World Ecology, 20(4), 309 - 316. https://doi.org/10.1080/13504509.2 013.795505

[51] Société du Groupe Sonelgaz. 2012. Renewable Energy and Energy Efficiency Program. Available in: http://www.aprue.org.dz/Programme_ENR_et_efficacite_energetique_ fr.pdf.

[52] Streck, C., Keenlyside, P., \& von Unger, M. (2016). The Paris Agreement: A New Beginning. Journal for European Environmental \& Planning Law, 13(1), 3 - 29. https://doi.org/10.1163/18760104-01301002

[53] Torras, M., \& Boyce, J. K. (1998). Income, inequality, and pollution: a reassessment of the environmental Kuznets Curve. Ecological Economics, 25(2), 147 - 160. https:// doi.org/10.1016/s0921-8009(97)00177-8

[54] Tucker, M. (1995). Carbon dioxide emissions and global GDP. Ecological Economics, 15(3), 215 - 223. https://doi.org/10.1016/0921-8009(95)00045-3

[55] United Nations. (2002). Johannesburg Summit: Algeria Profile. Available at: http:// www.un.org/esa/agenda21/natlinfo/wssd/algeria.pdf.

[56] Ur Rahman, Z., Chongbo, W., \& Ahmad, M. (2019). An (a)symmetric analysis of the pollution haven hypothesis in the context of Pakistan: a non-linear approach. Carbon Management, 10(3), 227 - 239. https://doi.org/10.1080/17583004.2019.1577179

[57] Verbeke, T., \& De Clercq, M. (2006). The income-environment relationship: Evidence from a binary response model. Ecological Economics, 59(4), 419 - 428. https://doi. org/10.1016/j.ecolecon.2005.11.011

[58] Wang, S. S., Zhou, D. Q., Zhou, P., \& Wang, Q. W. (2011). CO2 emissions, energy consumption and economic growth in China: A panel data analysis. Energy Policy, 39(9), 4870 - 4875. https://doi.org/10.1016/j.enpol.2011.06.032

[59] World Bank. (n.d.). WB data. Available in http://data.worldbank.org/indicator/ EN.ATM.CO2E.PC

[60] Zhang, J. (2021). Environmental Kuznets Curve Hypothesis on CO2 Emissions: Evidence for China. Journal of Risk and Financial Management, 14(3), 93. https://doi. org/10.3390/jrfm14030093 


\section{Appendix}

Table 1-a: Results of the Johansen cointegration tests (1995) for CO2 emissions

\begin{tabular}{|c|c|c|}
\hline \multirow{2}{*}{$\begin{array}{l}\text { Hypotheses } \\
\text { Cointegration Tests }\end{array}$} & \multicolumn{2}{|c|}{ H0/H1 } \\
\hline & $r=0 / r \geq 1$ & $r \leq 1 / r=2$ \\
\hline \multirow{2}{*}{$\begin{array}{l}\text { Trace statistics } \lambda \text { trace } \\
\text { Critical value }(\mathrm{CV})\end{array}$} & $107.64 * *$ & $36.974 * *$ \\
\hline & 44.657 & 27.973 \\
\hline Probability & 0.0000 & 0.0203 \\
\hline \multirow{2}{*}{$\begin{array}{l}\text { Statistics of MPV } \lambda \max \\
\text { Critical value }(\mathrm{CV})\end{array}$} & $69.354 * *$ & $23.371 * *$ \\
\hline & 28.437 & 23.635 \\
\hline Probability & 0.0000 & 0.0310 \\
\hline Cointegration Tests & $r \leq 2 / r=3$ & $r \leq 3 / r=4$ \\
\hline \multirow{2}{*}{$\begin{array}{l}\text { Trace statistics } \lambda \text { trace } \\
\text { Critical value }(\mathrm{CV})\end{array}$} & 12.589 & 0.0448 \\
\hline & 16.173 & 3.9673 \\
\hline Probability & 0.1612 & 0.8849 \\
\hline \multirow{2}{*}{$\begin{array}{l}\text { Statistics of MPV } \lambda \max \\
\text { Critical value }(\mathrm{CV})\end{array}$} & 12.143 & 0.0439 \\
\hline & 14.951 & 3.8875 \\
\hline Probability & 0.1436 & 0.8335 \\
\hline
\end{tabular}

Table 1-c: Results of Johansen cointegration tests (1995) for NOx emissions

\begin{tabular}{|l|c|c|}
\hline \multirow{2}{*}{$\begin{array}{l}\text { Hypotheses } \\
\text { Cointegration Tests }\end{array}$} & \multicolumn{2}{|c|}{ H0/H1 } \\
\cline { 2 - 3 } $\begin{array}{l}\text { Trace statistics } \lambda \text { trace } \\
\text { Critical value }(\mathrm{CV})\end{array}$ & $\mathbf{r}=\mathbf{0} / \boldsymbol{r} \geq \mathbf{1}$ & $\boldsymbol{r} \leq \mathbf{1} / \boldsymbol{r}=\mathbf{2}$ \\
\cline { 2 - 3 } & $49.47^{* *}$ & $47.078^{* *}$ \\
\hline Probability & 0.0000 & 31.047 \\
\hline $\begin{array}{l}\text { Statistique de la MPV } \\
\text { Critical value (CV) }\end{array}$ & $71.462^{* *}$ & 0.0003 \\
\hline Probability & 28.646 & $23.906^{* *}$ \\
\hline Cointegration Tests & 0.0000 & 0.0023 \\
\hline Trace statistics $\lambda$ trace & $\boldsymbol{r} \leq \mathbf{2} / \boldsymbol{r}=\mathbf{3}$ & $\boldsymbol{r} \leq 3 / \boldsymbol{r}=\mathbf{4}$ \\
\hline Critical value $(\mathrm{CV})$ & 14.534 & 0.0278 \\
\hline Probability & 16.564 & 4.065 \\
\cline { 2 - 3 } & 0.1138 & 0.7853 \\
\hline
\end{tabular}




\begin{tabular}{|l|c|c|}
\hline Statistique de la MPV & 14.857 & 0.0324 \\
\cline { 2 - 3 } Critical value (CV) & 15.363 & 3.983 \\
\hline Probability & 0.0677 & 0.7894 \\
\hline
\end{tabular}

NOTE: (1) MPV designates the maximum proper value. $(* *)$ Refers to the significance at the $5 \%$ threshold where we reject the $\mathrm{H} 0$ hypothesis at this threshold (5\%).

(2) The critical values obtained from these two tests correspond to the values added of Mackinnon (1999).

Table 2: Illustration of cointegration vectors (PGDP / PECO2 - PGDP / PESO2 - PGDP / PENOx)

\begin{tabular}{|c|c|c|}
\hline LM test statistic & Joint Jarque-Bera & $\boldsymbol{\alpha i ~ ( 3 )}$ \\
$\mathbf{( 1 )}$ & test statistic (2) & \\
\hline $29.647 * *$ & $11.0784 * * *$ & -0.1794 \\
$(0.0307)$ & $(0.0039)$ & $(-1.8462 * *)$ \\
\hline $33.1017 * * *$ & 1.6595 & -0.4578 \\
$(0.0087)$ & $(0.4877)$ & $(-2.6849 * * *)$ \\
\hline 19.846 & 1.1021 & -0.1796 \\
$(0.2821)$ & $(0.5673)$ & $\left(-3.8041^{* * *)}\right.$ \\
\hline
\end{tabular}

NOTE: (1): LM test statistic, designates the statistical test of correlation of the series (for the number of delay $\mathrm{p}=4$ ); it is based on the null hypothesis $\mathrm{H} 0$ relating to the absence of correlation of the series and 1 alternative hypothesis $\mathrm{H} 1$ relating to the presence of correlation of the series. (2): Joint Jarque-Bera test statistic is the statistical test of normality of the residuals for the number of lags $p=4$; it is based on the following two assumptions: (H0: the data follow a normal distribution and $\mathrm{H} 1$ : the data does not follow a normal distribution). (3): $\alpha$ i designates the error correction term for each polluting emission. (4): (***): significance at the $1 \%$ threshold; $(* *)$ : significance at the $5 \%$ threshold and $(*)$ : significance at the $10 \%$ threshold. (5): For the two tests of LM and Joint Jarque-Bera, denote the probabilities. 